\title{
KLINIKINIŲ SIMPTOMǓ REIKŠMĖ DIAGNOZUOJANT STOROSIOS ŽARNOS PAKITIMUS
}

\author{
Laurita Vaičaitė, Kotryna Valiukaitė, Justina Rugieniūtė \\ Lietuvos sveikatos mokslu universiteto Medicinos akademijos Medicinos fakultetas
}

Raktažodžiai: storosios žarnos vėžys, kolonoskopija.

\begin{abstract}
Santrauka
Storosios žarnos (kolorektalinis) vėžys yra trečias pagal dažnį onkologinis susirgimas pasaulyje, nors vystymosi eiga dažniausiai lèta, trunkanti dešimtmečius. Ankstyva storosios žarnos pakitimų diagnostika yra pagrindinis gydymo sėkmę lemiantis veiksnys. Nèra vieno specifinio klinikinio simptomo, būdingo storosios žarnos věžiui. Dalis pacientų, kuriems nustatomi storosios žarnos pakitimai, neturi jokių nusiskundimų. Tiksliausias tyrimas, kurio metu nustatomi storosios žarnos dariniai ir paimama biopsija histologiniam ištyrimui, yra kolonoskopija. Šiame tyrime trumpai apžvelgiami pacientų, kuriems kolonoskopijos metu rasti storosios žarnos pakitimai, dažniausi nusiskundimai ir jų ryšys su nustatytais pakitimais.

Tyrimo metodai. LSMU ligoninès Kauno klinikų Gastroenterologijos klinikoje atliktas retrospektyvinis tyrimas. Analizuoti pacientų, kuriems 2017-2018 m. atlikta kolonoskopija ir rasta neoplazinių pakitimų, ambulatorinių kortelių duomenys. Statistinè analizè atlikta naudojant Microsoft Excel 2010 ir IBM SPSS 25.0 programų paketus. Kiekybiniai duomenys pateikti kaip vidurkis, standartinis nuokrypis, reikšmès minimumas ir maksimumas. Kokybinių duomenų palyginimui naudotas chi $\left(\chi^{2}\right)$ kriterijus. Statistinès hipotezès tikrintos naudojant Mann Whitney U kriterijų. Duomenys laikyti statistiškai reikšmingais, kai reikšmingumo lygmuo $\mathrm{p}<0,05$.

Rezultatai. Nespecifinių gastrointestinalinių nusiskundimų turintiems pacientams dažniau nustatomas pažengęs onkologinis procesas, nei simptomų neturintiems. Trečdaliui asimptominių pacientų nustatomas piktybinis storosios žarnos navikas, todèl kolonoskopijos negalima laikyti pertekliniu tyrimu.
\end{abstract}

\section{Ivadas}

Storosios žarnos (kolorektalinis) vėžys yra trečias pagal dažnị onkologinis susirgimas pasaulyje. Kasmet užregis- truojama apie 1,8 mln. naujų atvejų ir 861 tūkst. mirčių [1]. $2019 \mathrm{~m}$. Lietuvoje registruota per 8 tūkst. kolorektalinio véžio atvejų [2]. Storosios žarnos véžys, lyginant su kitais onkologiniais susirgimais, išsiskiria lèta, dešimtmečiais trunkančia gerybinių pakitimų piktybejjimo eiga [3]. Ankstyva storosios žarnos pakitimų diagnostika yra pagrindinis gydymo sẻkmę lemiantis veiksnys. Yra duomenų, kad penkeriu metų išgyvenamumas, nustačius neišplitusį storosios žarnos piktybinį naviką, gali siekti net 90 procentų [4], todèl daugelyje šalių nacionaliniu mastu įdiegtos storosios žarnos vėžio prevencijos programos. Lietuvoje 50-74 m. pacientams kas dveji metai profilaktiškai atliekamas testas slaptam kraujui išmatose nustatyti (iFOBT). Jei testo rezultatas teigiamas, pacientas siunčiamas detalesniam ištyrimui dèl galimų navikinių pakitimų. Dažni pacientų skundai, esant pakitimų storojoje žarnoje - obstipacijos, tuštinimasis krauju, bendras silpnumas, krentantis svoris, neretai diagnozuojama anemija [5-7]. Vieno specifinio klinikinio simptomo, būdingo storosios žarnos vėžiui, nèra [7]. Dalis pacientų, kuriems nustatomi storosios žarnos pakitimai, neturi jokių nusiskundimų. Tiksliausias tyrimas, kurio metu nustatomi storosios žarnos dariniai ir paimama biopsija histologiniam ištyrimui, yra kolonoskopija [8]. Šiame tyrime trumpai apžvelgiame pacientų, kuriems kolonoskopijos metu rasta storosios žarnos pakitimų, dažniausius nusiskundimus ir jų ryšs̨ su nustatytais pakitimais.

Tyrimo tikslas - įvertinti ryši tarp paciento simptomų ir storosios žarnos pakitimų, nustatytų kolonoskopijos metu.

\section{Tyrimo objektas ir metodai}

Lietuvos sveikatos mokslų universiteto (toliau - LSMU) ligoninès Kauno klinikų Gastroenterologijos klinikoje atliktas retrospektyvinis tyrimas. Analizuoti pacientu, kuriems 2017-2018 m. atlikta kolonoskopija ir rasta neoplaziniu pakitimų, ambulatorinių kortelių duomenys. Iš ambulatorinio apsilankymo išrašo vertinti pacientų nusiskundimai (obstipacijos, melena ar šviežias kraujas tuštinantis, svorio kritimas, bendras silpnumas) ir laboratorinių tyrimų duomenys (anemija: hemoglobinas $<120 \mathrm{~g} / 1$, atlikus bendrą kraujo 
tyrimą prieš kolonoskopiją). Iš kolonoskopijos aprašymo vertinta storosios žarnos radinių struktūra, lokalizacija, darinio biopsijos histologinio tyrimo atsakymas (skirstyta ị nepiktybinius ir piktybinius (storosios žarnos vėžio) pakitimus. Statistinė analizè atlikta naudojant Microsoft Excel 2010 ir IBM SPSS 25.0 programų paketus. Kiekybiniai duomenys pateikti kaip vidurkis, standartinis nuokrypis, reikšmès minimumas ir maksimumas. Kokybinių duomenų palyginimui naudotas chi $\left(\chi^{2}\right)$ kriterijus. Statistinès hipotezės tikrintos naudojant Mann Whitney U kriterijų. Duomenys laikyti statistiškai reikšmingais, kai reikšmingumo lygmuo $\mathrm{p}<0,05$. Tyrimui atlikti gautas LSMU Bioetikos centro leidimas.

\section{Rezultatai}

Iš viso tyrime dalyvavo 111 pacientų. Iš jų 50 moterų ( 45,0 proc.) ir 61 vyras (55,0 proc.). Tiriamujų amžiaus vidurkis $64 \mathrm{~m} .( \pm 10 \mathrm{~m}$.), amžiaus intervalas nuo 21 iki 85 metų. Ivvertinus kolonoskopijos metu rastų storosios žarnos pakitimų histologinio bioptatų tyrimo rezultatus, 49 pacientams (44,1 proc.) rasti nepiktybiniai pakitimai, o 62 (55,9 proc.) diagnozuotas storosios žarnos véžys (adenokarcinoma). Atlikus kolonoskopiją nustatyta, kad storosios žarnos dariniai dažniausiai lokalizuojasi tiesiojoje (29,9 proc.) ir riestinejje žarnoje (24,1 proc.). Cirkuliariai augan-

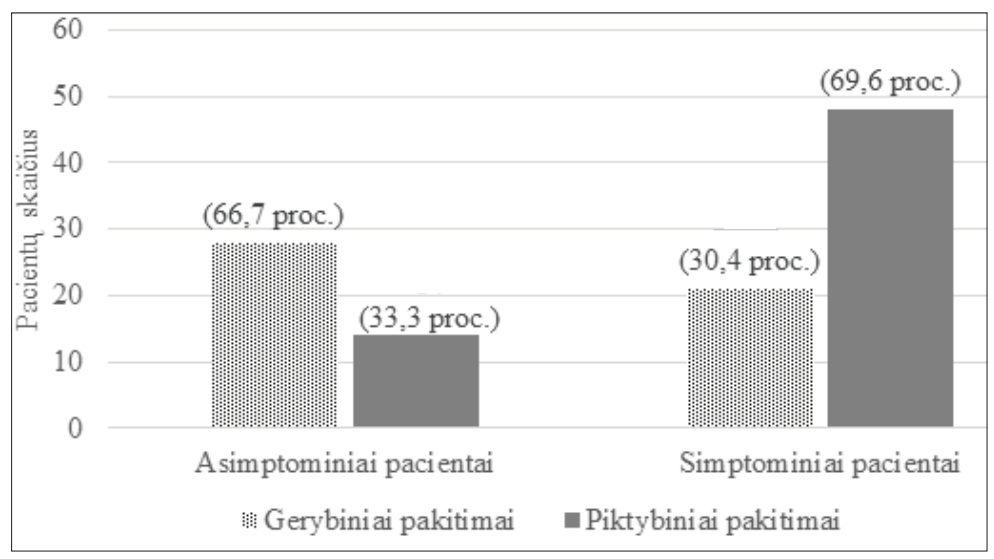

1 pav. Gerybinių ir piktybinių storosios žarnos pakitimų nustatymo dažnis tarp simptominių ir asimptominių pacientų

1 lentelẻ. Simptomų pasireiškimas ir piktybinio naviko nustatymo dažnis

\begin{tabular}{|l|c|c|}
\hline Simptomai & $\begin{array}{c}\text { Simptominių pacientų } \\
\text { skaičius (tirtụ pacientų } \\
\text { dalis, proc.) }\end{array}$ & $\begin{array}{c}\text { Pacientų, kuriems nustatytas } \\
\text { storosios žarnos věžys, skaičius } \\
\text { (simptominių pacientų dalis, } \\
\text { proc.) }\end{array}$ \\
\hline Anemija & $36(32,4)$ & $20(55,6)$ \\
\hline Obstipacijos & $10(9,0)$ & $7(70,0)$ \\
\hline $\begin{array}{l}\text { Tuštinimasis } \\
\text { krauju }\end{array}$ & $18(16,2)$ & $15(83,3)$ \\
\hline $\begin{array}{l}\text { Svorio } \\
\text { kritimas }\end{array}$ & $9(8,1)$ & $8(88,9)$ \\
\hline $\begin{array}{l}\text { Bendras } \\
\text { silpnumas }\end{array}$ & $10(9,0)$ & $9(90,0)$ \\
\hline
\end{tabular}

čių ir ženkliau spindị siaurinančių navikų nustatyta 51,6 procento. Iš visų tiriamujų, simptomų neturejo 42 pacientai ( 37,8 proc.), bent vieną nusiskundimą nurode 69 (62,2 proc.). Gerybinių ir piktybinių storosios žarnos pakitimų nustatymo dažnis tarp simptominių ir asimptominių pacientų pavaizduotas 1 paveiksle.

Nusiskundimus išsakiusių pacientų pasiskirstymas pagal simptomus ir piktybinio naviko nustatymo dažnis pavaizduotas 1 lenteleje.

Palyginus dvi pacientų grupes - simptomų nenurodžiusius ir nurodžiusius bent vieną simptomą, nustatyta, kad anemija, stebèta prieš kolonoskopiją atliktame bendrame kraujo tyrime, nesietina su piktybinio darinio nustatymu $(\mathrm{p}=0,235)$. Lyginant su ikivėžiniais pakitimais, storosios žarnos věžiui buvo būdingesni šie pakitimai: obstipacijos ( $\mathrm{p}=0,023)$, tuštinimasis krauju $(p=0,010)$, svorio kritimas $(p=0,037)$ bei bendras silpnumas $(p=0,003)$. Dažniausiai skundų neturi pacientai, kuriems nustatyti gerybiniai dariniai $(\mathrm{p}=0,007)$ arba piktybinis darinys riestineje žarnoje $(\mathrm{p}=0,018)$.

\section{Rezultatų aptarimas}

Tyrimo rezultatai atskleidè, kad trečdaliui nusiskundimų neturejjusių pacientų buvo nustatyti piktybiniai pakitimai, o tarp simptominių pacientu piktybiniai pakitimai buvo nustatyti kiek daugiau nei dviem trečdaliais atvejų. Mūsų rezultatai iš esmès koreliuoja su 2004-2012 m. atlikta retrospektyvine studija, kurioje analizuotas ryšys tarp naviko struktūros ir piktybiškumo bei radinių, atlikus kompiuterinès tomografijos (KT) kolonoskopiją, parodžiusią, kad simptomus (dažniausiai - tuštinimąsi krauju, obstipacijas, svorio kritimą) išsakantiems pacientams dažniau randami piktybiniai storosios žarnos pakitimai [7]. Be to, simptominès ligos atvejais navikai būna didesni, cirkuliarūs ir ženkliau siaurinantys žarnos spindị [6,7]. Nepaisant to, kad anemija mūsų tyrimo imtyje buvo dažniausias simptomas, reikšmingos sąsajos tarp jos bei piktybinių navikų pasireiškimo dažnio nebuvo nustatyta, tačiau jei pacientas nurodo obstipacijas, tuštinimąsi krauju, svorio kritimą, bendrą silpnumą (ar bent vieną iš šių simptomų), dideja tikimybè, kad bus nustatytas piktybinis onkologinis procesas. Nors šiandien ir pasigirsta svarstymų, kad kolonoskopija yra 
perteklinis tyrimas, nes storosios žarnos navikai daugeliu atveju auga lètai, netgi dešimtmečiais, atsižvelgiant ị šio tyrimo rezultatus, negalima vienareikšmiškai teigti, kad kolonoskopijos atlikimas asimptominiams pacientams nèra tikslingas. İvertinus tai, kad iFOBT testas gali būti ir klaidingai neigiamas, negalima ignoruoti paciento nusiskundimų, o reikia individualiai spręsti dèl kolonoskopijos atlikimo.

\section{Išvados}

1. Nespecifinių gastrointestinalinių nusiskundimų turintiems pacientams dažniau nustatomas pažengęs onkologinis procesas, nei simptomų neturintiems.

2. Trečdaliui asimptominių pacientų nustatomas piktybinis storosios žarnos navikas, todėl kolonoskopijos negalima laikyti pertekliniu tyrimu.

\section{Literatūra}

1. Latest global cancer data: cancer burden rises to 18.1 million new cases and 9.6 million cancer deaths in 2018. WHO 2018. https://www.who.int/cancer/PRGlobocanFinal.pdf.

2. Sveikatos statistika. Traumų ir nelaimingų atsitikimų stebėsenos sistemos duomenys. HI 2018. https://stat.hi.lt/default. aspx?report_id=169.

3. Brenner $\mathrm{H}$, Chen $\mathrm{C}$. The colorectal cancer epidemic: challenges and opportunities for primary, secondary and tertiary prevention. Br J Cancer 2018;119(7):785-792.

https://doi.org/10.1038/s41416-018-0264-x

4. Cancer facts and statistics. Am Cancer Soc 2020. https://www. cancer.org/research/cancer-facts-statistics.html.

5. Bohorquez M, Sahasrabudhe R, Criollo A, Sanabria-Salas M, Vélez A, Castro J et al. Clinical manifestations of colorectal cancer patients from a large multicenter study in Colombia. Medicine 2016;95(40):e4883.

https://doi.org/10.1097/MD.0000000000004883

6. Schneider C, Bodmer M, Jick S, Meier C. Colorectal cancer and markers of anemia. Eur J Cancer Prev 2018;27(6):530-538. https://doi.org/10.1097/CEJ.0000000000000397

7. Lee M, Hinshaw J, Kim D, Pickhardt P. Symptomatic versus asymptomatic colorectal cancer. Acad Radiol 2016;23(6):712717.

https://doi.org/10.1016/j.acra.2015.12.009
8. Issa I, Noureddine M. Colorectal cancer screening: an updated review of the available options. World J Gastroenterol 2017;23(28):5086.

https://doi.org/10.3748/wjg.v23.i28.5086

\section{SIGNIFICANCE OF CLINICAL SIGNS AND SYMPTOMS IN DIAGNOSING COLORECTAL LESIONS}

L. Vaičaitė, K. Valiukaitė, J. Rugieniūtè

Keywords: colorectal cancer; colonoscopy.

Summary

Colorectal cancer (CRC) is currently the third most common cancer worldwide. Although, the process of transformation from precancerous lesions to colorectal cancer is slow and it often takes decades. Early diagnosis of colorectal cancer is the key factor in treatment success.

Symptoms of CRC are mostly non specific or even absent. Colonoscopy is considered as the most valuable tool to confirm the presence of colorectal lesions and enables the taking of histological samples. This study is aimed to analyze the relationship between the clinical features and colonoscopy findings.

Methods: a retrospective study was carried out. Data was collected from medical charts of 111 consecutive patients, who have undergone colonoscopy and have been diagnosed with neoplastic changes of colon in the Department of Gastroenterology at Hospital of Lithuanian University of Health Sciences Kaunas Clinics between 2017 and 2018. Statistical analysis was processed using Microsoft Excel 2010 and IBM SPSS 25.0 software. Quantitative data were evaluated by calculating the average, standard deviation, minimum, and maximum values. The chi square $\left(\chi^{2}\right)$ criterion was used to compare the qualitative data. Nonparametric Mann Whitney's U criteria were used to test statistical hypotheses. Results were considered statistically significant at $\mathrm{p}<0.05$.

Results: symptomatic patients are more likely to be diagnosed with advanced oncological process in comparison to asymptomatic patients. One third asymptomatic patients were diagnosed with CRC. The significance of colonoscopy even in asymptomatic cases is undeniable.

Correspondence: kotryna.valiukaite@gmail.com

Gauta 2020-04-01 